\title{
Prognostic Value of Neutrophil/Lymphocyte Ratio (NLR), Platelet/Lymphocyte Ratio (PLR) and Mean Platelet Volume (MPV) In Patients with Colorectal Carcinoma [Izmir Oncology Group(IZOG) Study]
}

\section{Nötrofil/Lenfosit Oranı, Trombosit/Lenfosit Oranı ve Ortalama Trombosit Hacminin Kolorektal Karsinomlu Hastalardaki Prognostik Değeri [İzmir Oncoloji Grubu (IZOG) Çalışması]}

\author{
Utku Oflazoğlu ${ }^{1}$, Ahmet Alacacioğlư ${ }^{1}$, Işıl Somalı ${ }^{2}$, Melike Yüce ${ }^{1}$, Abdullah Murat Buyruk ${ }^{2}$, Umut Varol ${ }^{1}$, \\ Tarık Salman' ${ }^{1}$, Halil Taşkaynatan ${ }^{1}$, Yaşar Yıldız ${ }^{1}$, Yüksel Küçükzeybek ${ }^{1}$, İlhan Öztop ${ }^{2}$, \\ Mustafa Oktay Tarhan ${ }^{3}$ \\ ${ }^{1}$ Department Of Medical Oncology, Izmir Katip Celebi University Ataturk Training And Resarch Hospital, \\ Izmir, Turkey \\ ${ }^{2}$ Department Of Medical Oncology, Dokuz Eylul University, Izmir, Turkey \\ ${ }^{3}$ Department Of Medical Oncology, Institute Of Oncology, Dokuz Eylul University, Izmir, Turkey
}

\section{ÖZET}

Giriş ve Amaç: Önceden kolorektal kanser(KRK) genel sağkalım ve rekürrense etki edebilecek çeşitli faktörler tanımlanmıştır. Ancak bunların birkaçı prognostic marker olarak kabul edilir. Mevcut çalışmamızda nötrofil/lenfosit oranı(NLO), trombosit/lenfosit oranı(TLO) ve ortalama trombosit hacminin(OTH) KRK li hastalarada bir biobelirteç olarak potansiyelini araştırmayı amaçladık.

Yöntem ve Gereçler: Retrospektif olarak tanı anında metastaik olmayan ve en az 12 aylık takip periyodu sonrasında rekürrens gelişen, 2008-2014 yılları arasında tanı almış 336 KRK tanılı hastanın klinik ve demografik verilerini incelendik. NLO, TLO ve OTH değerlerini belirlemek içi ROC eğrisi analizi kullanıldık. Bulgular: Hastalar nüks eden ve etmeyen olarak 2 gruba kategorize edildi. 89 hastada $(\% 26,5)$ da takip periyodunda nüks gelişti. NLO $\leq 3.39$ olan grupta hastalıksız sağklaım 55.5 bulunurken NLO $>3.39$ olan grupta hastalıksız sağkalım 82.8 ay bulundu( $(\mathrm{p}<0.0001)$. TLO $\leq 183$ olan grupta hastalıksız sağklaım 57.8 ay bulunurken TLO $>183$ olan grupta ise hastalıksız sağkalım 78.7 ay bulundu (p: 0.016$)$. OTH $\leq 8.3$ olan grupta hastalıksız sağkalım 59.7 ay bulunurken OTH>8.3 olan grupta ise hastalıksız sağklaım 59.7 ay oarak bulundu (p: 0.057)

Tartışma ve Sonuç: Bizim çalışmamız NLO, TLO ve OTH seviyelerinin KRK tanılı hastalarda güvenilebilecek prognostic biyobelirteçler olabileceğini göstermiştir. Yeni tanı almış KRK Tanılı hastalardaki NLO, TLO ve OTH değerlerinin artan sitokin seviyesini ve buna bağlı olarak değişimleri yansıması olabilir.

Anahtar Kelimeler: kolorektal kanser, ortalama trombosit hacmi, trombosit/lenfosit oranı, nötrofil/lenfosit oran1, biyobelirteç

\footnotetext{
ABSTRACT

Introduction: There are various factors that have been determined to affect recurrence and survival in colorectal cancer (CRC). However, few of them exhibit so high a prognostic marker. The present study aimed to investigate the potential of neutrophil/lymphocyte ratio (NLR), platelet/lymphocyte ratio (PLR) and mean platelet volume (MPV) as prognostic markers in patients with CRC.

Methods: We retrospectively examined the demographic and clinical data of 336 patients with colorectal adenocarcinoma in 2008-2014, which recurred after a 12-month follow-up period; the patients had nonmetastatic cancer at the time of diagnosis. In order to find out NLR, PLR, and MPV cut-off values, ROC curve analysis was used.

Results: Patients were categorized into two groups according to positive relapse and negative relapse. 89 patients $(26.5 \%)$ experienced a relapse in the follow-up period. The group NLR $\leq 3.39$ had 55.5 months of disease-free survival $(p<0.0001)$ while the group NLR $>3.39$ had 82.8 months $(p<0.0001)$. The group PLR $\leq 183$ had 57.8 months, the group PLR $>183$ had 78.7 months $(p=0.016)$; the group MPV $\leq 8.3$ had 59.7 months, the group MPV>8.3 had 87.2 months; the group MPV>8.3 had 87.2 months and the group MPV $<8.3$ had 59.7 months $(\mathrm{p}=0.057)$.
} 
Discussion and Conclusion: Our study demonstrated that NLR, PLR and MPV levels can actually be relied on as a prognostic factor in patients with CRC. MPV, NLR and PLR values displayed by recently diagnosed patients with CRC may be a reflection of an increased cytokine level and thereby change depending on it.

Keywords: Colorectal cancer, mean platelet volume, platelet/lymphocyte ratio, neutrophil/lymphocyte ratio, biomarker

\section{Introduction:}

Colorectal cancer (CRC) represents the most prevalent cancer of the gastrointestinal system and ranks fourth among cancer cases in developed countries. The risk assessment factors for patients with colorectal cancer rely on the surgical pathology result. Although numerous factors have been determined to affect recurrence and survival, none of them exhibit so high a prognostic value as tumor stage. As these prognostic data are obtained through a costly process that requires surgical materials, more affordable, conveniently derivable and feasible new serum biomarkers will contribute to the risk identification.

In this context, new parameters that can be obtained through routine complete blood count, including neutrophil/lymphocyte ratio (NLR), platelet/lymphocyte ratio (PLR) and mean platelet volume (MPV), have recently and frequently been studied in various types of cancer. There is a complex interaction between local characteristics of a tumor and the host's inflammatory response which could predict earlier tumor relapse and mortality (1). Some studies focused on NLR and PLR, which are considered among the markers of systemic inflammatory response, and demonstrated that their levels might be associated with disease progression in operated patients with CRC $(1,2)$. Other studies further demonstrated that preoperative NLR levels higher than 4 or 5 were associated with negative outcome in a variety of cancers such as lung and ovary cancers apart from the CRC and increased PLR could represent a negative prognostic factor (1,3-5). MPV is an indicator of early platelet activation and it was measured to be higher in preoperative patients compared to healthy controls (6).

The present study aimed to investigate the prognostic effects of NLR, PLR and MPV on patients with CRC.

\section{Materials and Methods:}

The study included 336 patients who were diagnosed with colorectal adenocarcinoma at Izmir Katip Celebi University Ataturk Training and Research Hospital and Dokuz Eylul University Faculty of Medicine Medical Oncology Clinic between 2008 and 2014, and with a follow-up period of minimum 12 months. Metastatic patients at the time of diagnosis were excluded. Informed written consent was obtained from the participants.

We retrospectively analyzed the patient files to obtain data including age, gender, detailed disease history, curriculum vitae, date of operation, primary tumor location, histopathological characteristics of the tumor (histology, stage, grade, vascular invasion, lymphatic invasion, perineural invasion), and preoperative neutrophil, lymphocyte, platelet and mean platelet volume values. The preoperative data reflect the values measured at the time of examination. The neutrophil/lymphocyte ratio and platelet/lymphocyte ratio were calculated by dividing the neutrophil value with the lymphocyte value and the platelet value with the lymphocyte value, respectively.

All statistical analyses were performed with the SPSS 20.0 (Chicago, Illinois) package software. We used Chi-Square and MannWhitney $U$ Tests to analyze the data and $\mathrm{p}<0.05$ value was taken to indicate statistical significance. We analyzed the ROC (receiveroperating characteristic) curve to find out NLR, PLR, and MPV cut-off values (Figure 1) according to all patients, their stages and tumor grade. For the all patients, NLR cut-off value was $3.39(\mathrm{p}<0.0001)$, PLR cut-off value was 183 ( $\mathrm{p}=0.024)$, and MPV cut-off value was 8.3 $(\mathrm{p}=0.028)$. In stage 2 and 3 patients, the NLR cut-off value was 3.26 (p:0.007) and 3.02 $(\mathrm{p}<0.0001)$, PLR cut-off value was 181.9 $(\mathrm{p}=0.055)$ and $173(\mathrm{p}=0.14)$, and MPV cut-off value was $8.05(\mathrm{p}=0.051)$ and $8.27(\mathrm{p}=0.026)$. The disease-free survival (DFS) ratio and survival curves were compared by using the 
Kaplan-Meier method and long-rank test, respectively.

\section{Results:}

Of 336 patients, $211(62.8 \%)$ were male and $125(37.2 \%)$ were female. Mean age of the patients was $62.2 \pm 11.8$ years (33-86 years). Regarding tumor location, 270 (80.3\%) of the patients had a tumor in the colon and 66 $(19.6 \%)$ had a tumor in the rectum. A great majority of patients were comprised of Stage II
(160 patients, 47.6\%) and Stage III (149 patients, 44.3\%) cases. We used the TNM staging recommended by AJCC 6 (American Joint Committee on Cancer Recommendations) for this purpose. A pathological examination revealed that 85 patients $(25.3 \%)$ had a welldifferentiated tumor while $207 \quad(61.6 \%)$ exhibited moderately-differentiated and 44 $(13.1 \%)$ presented poorly-differentiated tumors. Patient characteristics are shown in Table 1.

Table 1. Clinical characteristics of the patients with colorectal cancer

\begin{tabular}{|c|c|}
\hline Characteristics of the patients & n $(\%)$ \\
\hline Age (years), Mean (range) & $62.2 \pm 11.8(33-86)$ \\
\hline \multicolumn{2}{|l|}{ Gender } \\
\hline Male & $211(62.8)$ \\
\hline Female & $125(37.2)$ \\
\hline \multicolumn{2}{|l|}{ TNM stage } \\
\hline Stage 1 & $27(8.0)$ \\
\hline Stage 2 & $160(47.6)$ \\
\hline Stage 3 & $149(44.4)$ \\
\hline \multicolumn{2}{|l|}{ Degree of differentiation } \\
\hline well-differentiated & $85(25.3)$ \\
\hline moderately-differentiated & $207(61.6)$ \\
\hline poorly-differentiated & $44(13.1)$ \\
\hline \multicolumn{2}{|l|}{ Disease status at last follow-up } \\
\hline Evidence of disease (ED) & $89(26.4)$ \\
\hline No evidence of disease (NED) & $247(73.6)$ \\
\hline \multicolumn{2}{|l|}{ Tumor localization } \\
\hline rectal & $66(19.6)$ \\
\hline colon & $270(80.3)$ \\
\hline \multicolumn{2}{|l|}{ The type of adjuvant Chemotherapy } \\
\hline XELOX & $224(\% 66.6)$ \\
\hline FOLFOX & $41(\% 12.2)$ \\
\hline Capesitabine & $44(\% 13.1)$ \\
\hline None & $27(\% 8)$ \\
\hline
\end{tabular}

Adress for correspondence: Dr. Utku Oflazoğlu Department of Medical Oncology, Izmir Katip Celebi University Ataturk Training and Resarch Hospital, 35330 İzmir, Türkiye e-mail: u.oflaz@mynet.com 
The patients were divided into two groups based on their relapse status. Eighty-nine (26.4\%) patients experienced a relapse, which was observed most frequently in liver (31 out of 89 patients had relapse in liver). It was followed by the anastomotic line (20 patients, $6 \%$ ) and lung (17 patients, $5.1 \%$ ).

In the group of patients with $\mathrm{NLR} \geq 3.39$ had 55.5 months of disease-free survival (DFS) $(p<0.0001)$ while the patients with NLR>3.39 had 82.8 months $(\mathrm{p}<0.0001)$ (Figure 2). The group PLR $\geq 183$ had 57.8 months, the group PLR>183 had 78.7 months ( $\mathrm{p}=0.016$ ); the group $\mathrm{MPV} \geq 8.3$ had 59.7 months, the group MPV>8.3 had 87.2 months $(\mathrm{p}=0.057)$. In stage 3 ; patients with NLR $\geq 3.02$ had 49.5 months of DFS while the patients with NLR>3.02 had 94.6 months $(p<0.0001)$, the patients with PLR $\geq 173$ had 54.8 months, the patients with PLR>173 had 88.1 months $(\mathrm{p}=0.033)$, the patients with MPV $\geq 8.27$ had 55 months, the patients with MPV>8.3 had 88.1 months $(\mathrm{p}=0.15)$. In stage 2 ; the patients with NLR $\geq 3.26$ had 56.6 months of DFS while the patients with NLR>3.26 had 70.2 months $(p<0.012)$, the patients with PLR $\geq 181.9$ had 60 months, the patients with PLR $>181.9$ had 69 months $(\mathrm{p}=0.11)$, the patients with $\mathrm{MPV} \geq 8.05$ had 62.3 months, the patients with MPV $>8.3$ had 63.5 months $(\mathrm{p}=0.19)$.

In multivariate analysis, we examined the patients' subgroups according to their NLR value, PLR value, MPV value, age, gender, grade, vascular invasion, lymphatic invasion, perineural invasion. The multivariate analysis demonstrated that NLR value and female gender were good prognostic factors in terms of DFS ( $p<0.0001$ and $\mathrm{p}: 0.031$, respectively). Prognostic factors affecting DFS were seen in Table 2.

Table 2: Prognostic factors affecting DFS (multivariate analysis)

\begin{tabular}{|l|c|c|}
\hline \multicolumn{1}{|c|}{ Prognostic Factors } & $\begin{array}{c}\text { Loss Chi- } \\
\text { square }\end{array}$ & Sig. \\
\hline $\begin{array}{l}\text { Neutrophil/lymphocyte } \\
\text { ratio }\end{array}$ & 16,275 & 0,000 \\
\hline Gender & 4,662 & 0,031 \\
\hline
\end{tabular}

\section{Discussion:}

The relationship between carcinogenesis and inflammation is well known with many types of cancer and inflammation represents a key stage in cancer progress (7). The complex interaction between local characteristics of a tumor and the host's inflammatory response could predict earlier tumor relapse and mortality (1). Taking this idea into account, some studies focused on NLR and PLR which are considered among the markers of systemic inflammatory response.

It is suggested that the physiological response of circulating leukocytes to stress triggers an increase in the number of neutrophils and a decrease in lymphocytes through the generation of granulocyte colony stimulating factor, tumor necrosis factor alpha as well as myeloid growth factors including interleukin-1 and interleukin-6 in the cancerous tissue (8), such an increased neutrophil concentration suppresses the lymphocyte activity and inhibits antitumor response, thereby resulting in tumor growth and metastasis $(9,10)$. Although it has been suggested that an imbalanced NLR or PLR could be associated with tumor growth and metastasis and it might play a prognostic role, their prognostic and predictive roles are demonstrated by a limited number of studies and this role remains a matter of debate. Compared to the control group, the patients with CRC presented significantly higher MPV, NLR and PLR levels in the preoperative period. Moreover, such levels were reported to have decreased significantly in the postoperative period, which was considered to be associated with the disappearance of inflammation after surgery (11). Other studies on CRC reported that low NLR was related to better disease-free survival (DFS) outcome compared to the patients with higher ratios, whereas high NLR was associated with the independent prognostic factor and poor prognosis $(12,13,14)$. Contrary to a large number studies that concluded increased NLR and PLR as a negative prognostic factor, we found that high preoperative NLR and PLR levels correlated with better disease-free survival on a statistically significant level. The relationship between increased lymphocyte ratio on the tissue level and good prognosis has 
been theoretically demonstrated; however, it is likely that neutrophil and lymphocyte levels measured by instant complete blood count might not be reflecting the actual values on the tissue level. In addition, increased cytotoxic $\mathrm{T}$ lymphocytes in the tissue might be due to an indirect decrease in the peripheral blood level. As a result of this might lead to increased NLR and PLR. These findings could have been interpreted more accurately if it was possible to analyze the actual lymphocyte ratio on the tissue level or in the tumor bed.

Figure 1: ROC Curves of NLR, PLR and MPV for preoperative patients MPV, mean platelet volume; NLR, neutrophil/lymphocyte ratio; PLR, platelet/lymphocyte ratio; ROC (receiver-operating characteristic.)

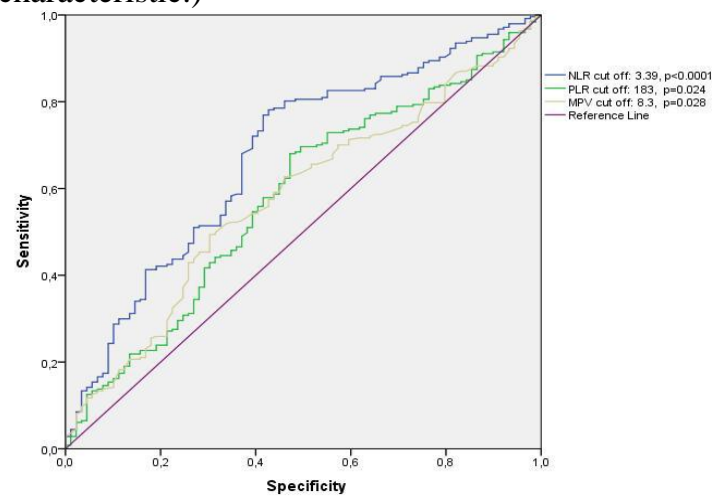

Figure 2: Kaplan-Meier Survival Curve for Disease-Free Survival according to the Neutrophil/Lymphocyte Ratio

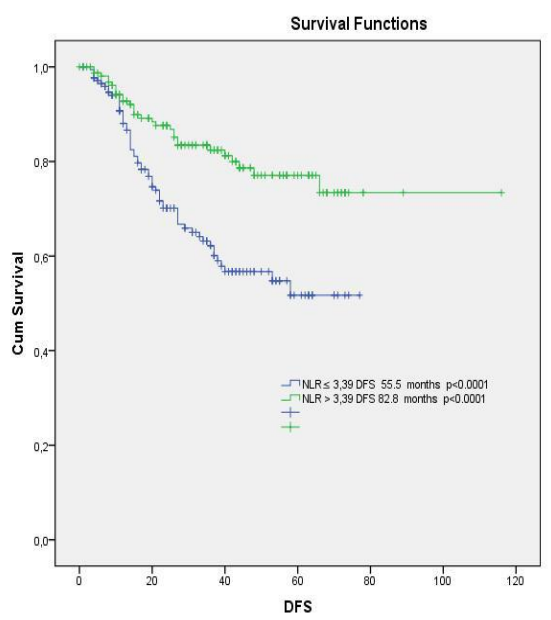

Thrombocytosis occurs after megakaryocytes stimulated by pro-inflammatory cytokines such as IL- 1 and IL- 6 and is considered an indicator of inflammation severity (15). Activated platelets release angiogenic growth factors and contribute to tumor angiogenesis and progression (16). Based on this idea, platelets are thought to play a significant role in cancer growth and metastasis (17), as a result of which MPV is considered a parameter that indicates inflammation (18) and is used for early detection of platelet activation (19). Recent studies revealed that MPV levels were relatively higher in tumor patients than in normal controls and associated with poor prognosis in some gastrointestinal neoplasms $(2,6,20)$. However, other studies have reported no difference between patients and controls in terms of MPV levels (21). In the present study, we found that patients with higher MPV levels displayed better DFS outcome in comparison to those with lower levels. Given the severity of preoperative inflammation, the immune systems of these patients could get be activated to a higher degree to produce a better outcome. However, high MPV is reported to indicate poor survival in malignant diseases which remains controversial $(19,22)$.

Although our study was conducted retrospectively, it has significance in two aspects. On the one hand, we showed that NLR, PLR and MPV, which can be obtained in a cost-effective and convenient way, might have a prognostic affect and thus reflect inflammation. Contrary to the relevant literature, high preoperative NLR, PLR and MPV levels could indicate a better disease-free survival. On the other hand, we presented a hypothesis that includes a possible discordance between actual levels measured by complete blood count and tissue levels.

This study investigated the hypothesis that MPV, NLR and PLR levels of recently diagnosed colorectal cancer patients might be the reflections of increased cytokine levels and the related inflammation and to present a prognostic marker to reveal such an inflammation in both a convenient and costeffective way. As a conclusion, we demonstrated that preoperative high NLR, PLR and MPV levels can actually be relied on as a prognostic factor in patients with CRC. Without doubt, given the relevant research in this field, prospectively designed studies examining lymphocyte levels on the tissue level will shed more light on this matter.

\section{Conflict of Interest: None}




\section{References}

1. Walsh SR. Cook EJ, Goulder F, et al: Neutrophil lymphocyte ratio as a prognostic factor in colrectal cancer. J Surg Oncol, 2005; 91: 181-4

2. Kurt M, Onal IK, Sayılır AY et al: The role of mean platelet volume in the diagnosis of hepatocellular carcinoma in patients with chronic liver disease. Hepatogastroenterology, 2012; 59: 1580-1582.

3. Cho H, Hur HW, Kim SH et al: Pre-treatment neutrophil to lymphocyte ratio is elevated in epithelial ovarian cancer and predicts survival after treatment. Cancer Immunol Immunother, 2009; 58: $15-23$

4. Shimada $\mathrm{H}$, Takiguchi $\mathrm{N}$, Kainuma $\mathrm{O}$ et al: High preoperative neutrophil to lymphocyte ratio predicts poor survival in patients with gastric cancer. Gastric Cancer, 2010; 13:170-176

5. Yao Y, Yuan D, Liu $\mathrm{H}$ et al: Pre-treatment neutrophil to lymphocyte ratio is associated with response to therapy and prognosis of advanced nonsmall cell lung cancer patients treated with first-line platinum-based chemotherapy. Cancer İmmunol İmmunother, 2013; 62:471-479

6. Kilınçalp S, Ekiz F, Başar O et al: Mean platelet volume could be possible biomarker in early diagnosis and monitoring of gastric cancer. Platelets. 2014; 25(8):592-4.

7. Balkwill F, Mantovani A.: Inflammation and cancer: back to Virchow? Lancet. 2001; 357: 539-45

8. Feng JF, Huang Y, Chen QX: Preoperative platelet lymphocyte ratio (PLR) is superior to neutrophil lymphocyte ratio (NLR) as a predictive factor in patients with esophageal squamous cell carcinoma. World J Surg Oncol. 2014;12: 58

9. Coussens LM, Werb Z.: Inflammation and cancer. Nature. 2002; 420: 860-7

10. Petrie HT, Klassen LW, Kay HD.: Inhibition of human cytotoxic $\mathrm{T}$ lymphocyte activity in vitro by autologous peripheral blood granulocytes. J Immunol. 1985; 134: 230-4

11. Kilincalp S, Çoban Ş, Akinci $H$, et al: Neutrophil/lymphocyte ratio, platelet/lymphocyte ratio, and mean platelet volume as potential biomarkers for early detection and monitoring of colorectal adenocarcinoma. Eur J Cancer Prev. 2015 Jul;24(4):328-33

12. Gennaro Galizia, Eva Lieto, Anna Zamboli, et al: Neutrophil to lymphocyte ratio is a strong predictor of tumor recurrence in early colon cancers: A propensity score-matched analysis Surgery. 2015 Jul;158(1):112-20

13. Malietzis G, Giacometti M, Askari A etal. Preoperative Neutrophil to lymhocyte ratio of 3 predicts disease-free survival after curative elective colorectal cancer surgery. Ann Surg. 2014; 260:28792

14. Ozdemir Y, Akin ML, Sucullu I, Balta AZ, Yucel E.: Pretreatment neutrophil/lymphocyte ratio as a prognostic aid in colorectal cancer. Asian Pac J Cancer Prev, 2014; 15: 2647-50

15. Alexandrakis MG, Passam FH, Moschandrea IA, Christophoridou AV, Pappa CA, et al. Levels of serum cytokines and acute phase proteins in patients with essential and cancer-related thrombocytosis. Am J Clin Oncol. 2003; 26(2): 135-40

16. Zhang $W$, Dang $S$, Hong $T$ et al.: A humanized single-chain antibody against beta 3 integrin inhibits pulmonary metastasis by preferentially fragmenting activated platelets in the tumor microenvironment. Blood. 2012; 120: 2889-98

17. Nash GF, Turner LF, Scully MF, Kakkar AK. Platelets and cancer. Lancet Oncol 2002; 3: 425-30

18. Altınbas S, Togrul C, Orhan A, Yücel M, Danısman $\mathrm{N}$. .: Increased MPV is not a significant predictor for preeclampsia during pregnancy. J Clin Lab Anal 2012; 26:403-6

19. Inagaki $N$, Kibata $K$, Tamaki $T$, Shimizu $T$, Nomura S. Prognostic impact of the mean platelet volume/platelet count ratio in terms of survival in advanced non-small cell lung cancer. Lung Cancer. 2014; 83: 97-101

20. Karaman K, Bostanci EB, Aksoy E, et al.: The predictive value of mean platelet volume in differential diagnosis of nonfunctional pancreatic neuroendocrine tumors from pancreatic adenocarcinomas. Eur J Intern Med. 2011; 22:95-8

21. Bayhan Z, Zeren S, Kocak FE et al: Diagnistic Value of the neutrophil to lymphocyte ratio and the platelet to lymphocyte ratio in patients with gastric carcinoma. Acta Medica Mediterranea, 2016, 32: 111

22. Aksoy S, Kilickap S, Hayran $M$ et al.: Platelet size has diagnostic predictive value for bone marrow metastasis in patients with solid tumors. Int J Lab Hematol. 2008;30(3):214-9 